\title{
Missionários, índios e sociedade colonial no nordeste da Bahia: Natuba, séculos XVII e XVIII*
}

\author{
por \\ Evergton Sales Souza ${ }^{1}$ \\ Universidade Federal da Bahia/CNPq
}

\begin{abstract}
O artigo estuda aspectos da conquista e povoamento do nordeste da Bahia, privilegiando o olhar sobre o lugar dos índios na ocupação colonial de novos espaços. A aldeia de Natuba foi tomada como a principal referência para o estudo do contexto de violência que marca o avanço da sociedade colonial na região. Após examinar o problema da demarcação de terras, que envolve índios, missionários, governo e colonos, mostra-se como a aldeia missionária tendeu a ser um espaço menos instável, permitindo aos indigenas trilharem um caminho de reconfigurações que ajudou a manter sua identidade e influenciar o catolicismo vivido no nordeste baiano.
\end{abstract}

PalaVRas-ChaVe: Brasil colonial; índios; sociedade colonial; missionários.

Cómo citar este artículo / Citation: Sales Souza, Evergton, "Missionários, índios e sociedade colonial no nordeste da Bahia: Natuba, séculos XVII e XVIII", Revista de Indias, LXXIX/276 (Madrid, 2019): 339-367. https://doi.org/10.3989/revindias.2019.010.

O principal dos Indios da Natuba cometeo hum crime antigamente contra os Brancos matando hum Capitão; então todos os Brancos se derão por inimigos dos

* O presente artigo é resultado de pesquisas financiadas pela FAPESB, Fundação de Amparo à Pesquisa do Estado da Bahia, CNPq e CAPES. Também está associado ao Projeto Bahia 16-19 - Salvador da Bahia: American, European and African forging of a colonial capital city, Marie Curie Actions, IRSES, GA-2012-318988 (CHAM-FCSH-UNL \& UA; EHESS; UFBA) e ao Projeto RESISTANCE 778076-H2020-MSCA-RISE-2017.

Meus agradecimentos aos colegas Fabrício Lyrio Santos, João José Reis, Lígia Bellini, Maria Rosário G. de Carvalho e Rafael Chambouleyron pelas críticas e sugestões que fizeram a versões anteriores deste texto.

1 evergtons@gmail.com, ORCID iD: https://orcid.org/0000-0001-7466-6276. 
Indios da Natuba, \& de todos os Kiriris, por serem todos da mesma Nação do principal criminoso; por isso captivárão todos que poderão prender ${ }^{2}$.

Crivado de flechas, o capitão-mor Agostinho Pereira Bacellar era só um corpo sem alma. Em outubro de 1677, toda a sua experiência nas lides dos sertões que iam sendo desbravados não lhe valeu3 ${ }^{3}$. Foi morto na aldeia de Natuba, onde, atendendo às ordens do governo-geral, tinha ido buscar 120 homens com flechas para fazer guerra a outros índios ${ }^{4}$. É possível que tivesse sido surpreendido, sem informações prévias sobre o estado de espírito daquela aldeia Kiriri. A notícia de sua morte não tardou a chegar à capital do Brasil, tendo algum mensageiro percorrido rapidamente os cerca de 200 quilômetros que separavam o local do acontecimento da cidade da Bahia 5 . A junta governativa, formada por Cristóvão de Burgos, Álvaro de Azevedo e Antônio Guedes de Brito, não tardou a reagir ao levante daqueles índios, enviando homens armados para buscar os culpados pelo crime. Na patente do posto de Capitão-mor da jornada que se faria à aldeia de Natuba, concedida a Domingos Rodrigues de Carvalho, dizia-se que o falecido Agostinho Pereira Bacellar havia ido cumprir a ordem de buscar índios nas aldeias do Itapicuru-mirim, Massacará e Natuba, necessários à jornada do sertão para a qual havia sido enviado o Governador da Conquista, o paulista Estevão Ribeiro Bayão Parente 6 . Após recolher alguns índios nas duas primeiras aldeias, chegou a Natuba, onde o seu principal recu-

2 Mamiani, 1698: 140. No Catecismo, o trecho citado tem por objetivo explicar aos índios como o pecado original, de Adão e Eva, se comunica a toda a humanidade. Por meio de uma analogia tenta-se fazer entender como os pecados dos antepassados passam às sucessivas gerações.

3 Em fins de 1654, já aparecia como sargento-mor da jornada que deveria castigar os índios que atacavam o recôncavo baiano e que chegou ao sertão das Jacobinas. Na ocasião, estava subordinado ao seu irmão, Gaspar Roiz Adorno, nomeado Capitão-mor pelo Governador-Geral, Conde de Atouguia. Documentos Históricos, 1928, 5: 238. Para mais informações sobre a referida jornada do sertão ver Documentos Históricos, 1928, 5: 232-237.

4 Documentos Históricos, 1928, 9: 50.

5 Num mapa feito, provavelmente, em 1758, estimava-se a distância entre Natuba e Cachoeira em 40 léguas e dizia-se que "os escoteiros consomem quatro dias". Calcular a distância percorrida por um viajante sem bagagem em dez léguas por dia parece ser uma estimativa bastante comum para a época. Arquivo Histórico Ultramarino, Lisboa (AHU), Conselho U1tramarino (CU), Bahia Avulsos, cx. 138, doc. 10.673 (por engano em 10.674).

6 A patente de Governador da Conquista foi dada a Estevão Ribeiro Baião Parente pelo Governador-Geral Afonso Furtado de Castro do Rio de Mendonça, em 4 de agosto de 1671. Interessante notar que, normalmente, sua patente seria a de capitão-mor da conquista, mas "por causa de sua tardança", o governador nomeou Brás Roiz de Arzão, que vinha para ser sargento-mor, para aquele posto. Para evitar o desdouro de Arzão e não deixar de ter Baião Parente no comando da ação, Afonso de Mendonça o nomeou Governador da gente auxiliar que veio de São Paulo e o mais que nesta Capitania se lhe agregar, assim brancos como Índios, 
sou-se a aceitar a carta enviada pelo governo e a obedecer as ordens de Agostinho Pereira, matando-o "às frechadas atrozmente"7. Por esta razão, em consulta geral realizada sobre o assunto, a junta governativa resolveu ordenar a prisão dos cabeças daquele levante e principais culpados da morte do capitãomor. Entretanto, se houvesse algum estorvo à realização das prisões e os índios oferecessem resistência armada, entender-se-ia que seria o caso de proceder contra a aldeia nos termos determinados pela lei filipina de 10 de setembro de 1611 , que regulava a "guerra justa" contra os gentios do Brasil'. Noutras palavras, a resistência implicaria em guerra e, posteriormente, a depender da decisão da junta, em escravização dos índios que fossem aprisionados.

Este artigo retoma alguns aspectos interpretativos concernentes ao modo como se desenvolveu a dominação colonial, nomeadamente no que respeita às disputas envolvendo o célebre tripé formado por coroa, missionários e colonos. Por meio da redução da escala espacial — limitada à aldeia de Natuba e, quando necessário, às aldeias situadas no Nordeste da capitania da Bahia - e do recurso a uma perspectiva de longa duração, busca-se mostrar nuances e diferenças internas atinentes a esses três polos, bem como observar escolhas, estratégias e divisões entre aqueles que estão no centro de seus interesses e disputas: os índios.

\section{A aldeia de Natuba e o Nordeste da Bahia}

\section{a) Colonização e missionação. Esforço de contextualização histórica ${ }^{9}$}

Situada em local bem próximo às margens do Rio Natuba, a aldeia foi formada, provavelmente, na segunda metade dos anos $1660^{10}$. A primeira

para a conquista dos Bárbaros. Encontra-se transcrição da patente em Francisco Borges de Barros (Barros, 1919: 192-193). Ver também Documentos Históricos, 1928, 6: 192.

7 Documentos Históricos, 1928, 13: 17. Esta mesma passagem seria mencionada por Pedro Calmon (Calmon, 1959: 752).

8 Silva, 1854: 309-312.

9 Em recente artigo, Guida Marques (Marques, 2014: 15-48) analisa o contexto da conquista dos sertões baianos, na segunda metade do século XVII, focando sobre os discursos e representações que visavam justificar a guerra contra os índios. Trata-se de um estudo que contribui para compreender, a partir de um enquadramento analítico diferente do que se propõe aqui, alguns aspectos relativos ao contexto baiano da última metade do Seiscentos.

10 Ver mapas ao final deste artigo. 
missão jesuítica a penetrar aqueles sertões e chegar ao que chamavam de Jacobinas data de 1656, mas não é certo que tenha passado pela região de Natuba, situada a mais de $200 \mathrm{~km}$ a Leste das serras da Jacobina, em região próxima às margens do Rio Itapicuru ${ }^{11}$. A referida missão foi feita com o apoio do governador-geral, D. Jerônimo de Ataíde, Conde de Atouguia. O padre Simão de Vasconcelos, em carta de 2 janeiro de 1656, dizia ao prepósito da Companhia de Jesus, em Roma, que no ano anterior o governador havia organizado uma tropa para "fazer guerra a certos selvagens, que assalteavão nossos confins". Dessa jornada chegaram as notícias da existência de um "quase reino de índios manços, dóceis e da mesma nação e língua que os que hoje temos nas Aldeas, chamãose estes Amoypiras"12. Em razão disso, os jesuítas se animaram a realizar a missão para a qual foi designado o padre Rafael Cardoso, que seguiu com uma tropa organizada pelo governo e capitaneada pelo cabo dos índios, o capitão João Pereira ${ }^{13}$. Talvez se possa indicar este momento como aquele a partir do qual alguns jesuítas começaram a missionar na região, contribuindo para que um novo elã missionário viesse à tona.

Pouco mais de dez anos antes, a situação das missões indígenas era bem diferente, pois os religiosos pareciam não fazer qualquer movimento para penetrar nos sertões e engajar-se na tarefa de converter os numerosos tapuias ${ }^{14}$ que neles se encontravam. Numa carta de 3 de maio de 1650, o padre inaciano Manoel Dinis pedia aos seus superiores autorização para passar à Índia. O

11 Há relativo consenso em relação à indicação da segunda metade do século XVII como momento de construção dessas missões no sertão Nordeste da Bahia. O capítulo de Beatriz G. Dantas, José Augusto L. Sampaio e Maria Rosário G. de Carvalho (Dantas, Sampaio e Carvalho, 1992: 431-456) continua sendo uma referência importante sobre o assunto. Há que se corrigir, contudo, a referência ao ano de 1639 como sendo o da fundação da aldeia do Massacará. Como se verá adiante, propomos que essa aldeia foi criada no mesmo momento de expansão missionária da segunda metade do século XVII.

12 Archivum Romanum Societatis Iesum, Roma (ARSI), Bras., 3-1, fl. 300. A jornada à qual se refere é muito provavelmente aquela comandada por Gaspar Roiz Adorno. Ver referências indicadas acima, na nota 2.

13 ARSI, Bras., 3-1, f1. 300. Documentos Históricos, 1928, 31: 182. Uma descrição dos resultados dessa missão encontra-se na relação do sexênio 1651-1657 feita pelo padre Antônio Pinto. Sabe-se, por essa relação, que os amoipiras não foram encontrados naquela região das Jacobinas, mas que, espalhadas pelos vales e montes, havia 80 aldeias de tapuias, principalmente Sapoiá e Paiaiá. ARSI, Bras., 9, fls. 16v-18v. Este documento também é referido por Serafim Leite (Leite, 1945: 271).

14 Tapuia, como é sabido, não é um etnônimo, mas um termo usado no período colonial para classificar todos os povos indígenas que não estivessem enquadrados no contexto cultural e linguístico dos tupis. Cristina Pompa (Pompa, 2003b: 9-11) faz uma análise muito esclarecedora sobre o assunto. 
argumento avançado para justificar a sua transferência corrobora o que foi dito aqui sobre o estado das missões indígenas:

... entrei na província do Brazil com desejo da salvação de minha alma e ainda da gentilidade, e como nesta província já hoje não vão buscar gentio e o que há he já doutrinado e tem abundancia de sogeitos que o conservem, dame Deus nosso senhor desejo de passar a Índia com o Pe. Antônio Velozo procurador de Cochim...15

Pode-se objetar que há possibilidade de exagero por parte do jesuíta, afinal, em seu desejo de passar para a Índia, apresentar este quadro poderia reforçar a chance de ver seu pedido atendido. Ainda assim, não é crível que forçasse demasiado esta realidade que era acompanhada pelo generalato da Companhia através de múltiplas correspondências, inclusive das cartas ânuas. Outra questão a assinalar é a de que, em 1656, já havia muitos anos que não eram encontrados nos sertões baianos índios chamados de língua geral, Tupi. O próprio padre Simão de Vasconcelos, provincial da Companhia de Jesus, afirmou isto em carta na qual mostrava seu entusiasmo com as notícias da existência de Amoipiras nos sertões das Jacobinas ${ }^{16}$. O modo como trata o assunto é relevante por sugerir que, até aquele momento, ao menos no colégio da Bahia, ainda não havia sido tomada uma resolução em torno da possibilidade e/ou necessidade de buscar a conversão dos tapuias. Assim, pode-se intuir que o novo impulso missionário teve em seu ponto de partida a notícia sobre os Amoipiras, mas não foi o encontro de índios de língua geral que permitiu o seu efetivo desenvolvimento, pois, passadas algumas décadas, no final do século XVII, o governador-geral João de Lencastre afirmava, peremptoriamente, que já não havia índios de língua geral para se reduzirem à fé17!

Os indícios levam a crer que na década de 1656 a 1665 ocorreu o amadurecimento de uma visão dos missionários acerca da possibilidade da conversão dos tapuias. E, neste contexto, é correto dizer que os jesuítas Jacob Roland e João de Barros foram os pioneiros das missões religiosas nos sertões do Nordeste da Bahia ${ }^{18}$. Aldeias como Natuba, Canabrava, Saco dos Morcegos, Massacará, Jeremoabo e Jacobina, parecem ter sido formadas na mesma época,

15 ARSI, Bras. 3-1, fl. 279.

16 ARSI, Bras. 3-1, fl. 300.

17 Arquivo da Universidade de Coimbra, Coimbra (AUC), Col. Conde dos Arcos, VI-31-1-5, fl. 686v-687: "No arcebispado da Bahia, não há já Indios de língua geral para se reduzirem a fé. Somente no certão mais remoto há tapuyas Barbaros de diversas línguas que vivem em ranchos e passão de hum lugar para outro para comerem os frutos silvestres, que dão em vários tempos do ano".

18 Leite, 1945: 280-286 e 293-296. 
seguindo o mesmo elã missionário iniciado pelos jesuítas ${ }^{19}$. Porém, é preciso lembrar que a região dos sertões do Itapicuru de cima, estendendo-se às terras do sub-médio e parte do baixo São Francisco, já ia sendo, ainda que muito lentamente, objeto de conquista territorial e colonização portuguesa. É o que se depreende de uma carta de sesmaria de dez léguas de terras, alastrando-se ao longo do Rio Inhambupe, dada a Francisco Dias D'Ávila, em agosto de $1621^{20}$. Mais ao Norte, na região do Vaza Barris, há notícia de uma sesmaria concedida ao capitão Antonio Camello Pegas, em 1634. Entretanto, a terra havia retornado para a coroa por jamais ter sido cultivada e, em 1657, foi objeto de nova concessão, desta vez para Felipa Pereira, viúva de Camello Pegas $^{21}$. Os vestígios documentais reforçam a ideia de que foi mesmo na década de 1650 que a colonização do Nordeste da Bahia tornou-se mais intensa e efetiva. Assim, quando os jesuítas resolveram empreender a conversão dos gentios daqueles sertões, fizeram-no podendo contar com alguma experiência que, provavelmente, adquiriram com militares e colonos que moravam ou já haviam estado naquelas áreas — a referida jornada do sertão, de 1656, é um exemplo eloquente disso. Por outro lado, os numerosos índios que habitavam a região deviam estar cada vez mais habituados com a presença de mamelucos, negros, brancos e índios de diferentes etnias.

Correspondências do Conde da Torre, datadas de fins dos anos 1630, fornecem indícios importantes sobre as relações que se foram estabelecendo com os índios daquela região, permitindo ver o quanto estiveram ligadas ao conflito com os holandeses. Em 8 de agosto de 1639, o Conde da Torre levava à junta formada por ele, pelo Conde de Bagnolo, mestre de campo general, D. Francisco de Moura, dos conselhos de Estado e Guerra, Luis Barbalho Bezerra, mestre de campo, padre João de Oliva, reitor do colégio dos jesuítas e pelo padre mestre Paulo da Costa, a proposta de transferir índios da vizinhança da cidade da Bahia para a região de Itapicuru, onde "pudessem fazer suas rossarias e sustentarse". Tendo em vista a informação de que esta transferência poderia acarretar sérios problemas, pois, havia risco dos índios "se passarem a Pernambuco aos Olandezes", o Conde da Torre pediu o parecer do capitãomor dos índios, António Filipe Camarão. Este propôs que "os índios que herão inviados com as molheres e meninos não tornassem atrás e seguissem seu caminho te a paragem dentre os rios Tapecuru e rio Real, que he paragem fértil e, que eles mesmos tinhão eleito"22. Esta região indicada por Camarão

\footnotetext{
19 Serafim Leite chegou à mesma conclusão. Leite, 1945: 280-292.

20 Documento transcrito em Silva, 1919, vol. 1: 451.

21 Documentos Históricos, 1928, 19: 348.

22 Salvado e Miranda, 2001: 294-296.
} 
pode ser aquela que compreendia parte das terras de Belchior Dias, além de uma larga porção de terra em que mais tarde se estabeleceriam as aldeias dos boimés, em Itapicuru, e, um pouco mais longe, a montante do rio do mesmo nome, a de Natuba ${ }^{23}$. O documento também reforça o caráter fundamental das guerras holandesas como vetor de ocupação e colonização daquelas terras ${ }^{24}$.

$\mathrm{Na}$ segunda metade da década de 1660, já expulsos os holandeses do Nordeste do Brasil, a situação se mostrava favorável à ação missionária, mas nem por isso as coisas foram fáceis. Com efeito, à relativa facilidade encontrada no terreno para a formação de aldeias indígenas, como a dos Mongurus, em Jeremoabo, dos Kaimbé, no Massacará, dos Kiriri/Meriti no Saco dos Morcegos e em Canabrava, dos Boimé, em Itapicuru, sucederam os problemas na cidade da Bahia. Em primeiro lugar, no próprio colégio da Companhia de Jesus, onde era preciso convencer os demais religiosos da necessidade de mudar a estratégia adotada até então em relação às missões indígenas. $\mathrm{O}$ padre João de Barros, escrevendo em 1667, acreditava que, em poucos anos, as terras do interior baiano, habitadas por tantos gentios, estariam repletas de cristãos, bastando para isso que os missionários se dispusessem a "fazer aldeas neste Certão"25. Resistência mais renhida foi a que apresentaram os grandes

23 As informações fragmentadas tornam extremamente difícil o estabelecimento da localização exata dos lugares mencionados. No presente caso, por exemplo, embora tenha buscado conjugar uma série de informações para chegar a alguma conclusão sobre o ponto entre o Itapicuru e o Rio Real mencionado no documento, as dúvidas persistem. Uma descrição de fins do século XVII revela a existência de três caminhos a ligar a Bahia a Pernambuco: a estrada da costa, outro chamado de caminho da mata ou do sertão do meio, cujo trajeto apresentaria alguma similaridade com a atual estrada BR-110, e, por fim, um terceiro, do sertão de cima, que toma a direção das Jacobinas. Annaes da Bibliotheca Nacional do Rio de Janeiro, 1909: 23-25. A distância longitudinal entre os dois primeiros caminhos, que são os que interessam aqui, seria de cerca de 30 léguas. Entretanto, esta distância, no trecho indicado, era bem menor. Entre as atuais cidades de Itapicuru e Rio Real, por exemplo, a distância é de $42 \mathrm{~km}$. A estrada das boiadas, em fins do século XVII, passava por esta região, junto à aldeia de Itapicuru e, mais ao Norte, ladeando Campos do Rio Real, que é a atual cidade de Tobias Barreto, em Sergipe. Ver, entre outros, a obra de Francisco Borges de Barros (Barros, 1919: 280-281). Sobre os caminhos dos sertões baianos ver também o importante estudo de Márcio Roberto Alves dos Santos (Santos, 2017: 159-191).

${ }^{24}$ Um documento de 1719 sugere até mesmo a participação, nas campanhas contra os holandeses, de índios que depois seriam aldeados em Natuba. O documento refere a uma petição do padre Antonio de Andrade, da Companhia de Jesus, na qual solicitava ajuda de custo para a construção da Igreja de Natuba, alegando que os índios eram merecedores da mercê régia, pois seus avós haviam defendido a terra "à custa do seu sangue e vida, expulsando daquelas terras vizinhas os holandeses que a tinham ocupado". Documentos Históricos, 1928, 97: 196.

25 ARSI, Bras. 3-II, fl. 51. 
senhores de terras, em particular os da Casa da Torre. Em março de 1669, segundo os testemunhos dos padres João de Barros e Jacob Roland, Garcia D’Ávila mandou destruir as igrejas que eles haviam construído nas aldeias de Massacará, Jeremoabo e Itapicuru. Os missionários não ocultam o fato de que eram igrejas pobres, cobertas com tetos de palha "como era habitual nesses lugares" — sicut mos est in illis locis, dizia o padre João de Barros-, mas a pobreza não lhes retirava o caráter de lugares sagrados onde havia altar e crucifixo, onde se celebravam missas, ouviam-se confissões e ministravam-se os sacramentos do batismo e da eucaristia ${ }^{26}$. O procedimento violento denota a força e prepotência dos senhores da Casa da Torre, que não temeram o escândalo de pôr igrejas abaixo, nem titubearam em opor-se aos jesuítas a fim de não permitir qualquer questionamento sobre a propriedade de suas terras. O motivo da ação intempestiva teria sido a notícia de que o padre Jacob Roland "havia de pedir para cada aldea três legoas de terra para os Indios roçarem"27. No entender do padre Antonio Pereira, tio de Garcia D’Ávila, tendo em vista que as aldeias eram muitas "ficaria ele sem terra". Diante de tal ameaça, dizia ele, qualquer senhor de terras teria o direito de defender seu patrimônio, "ainda com damno do offendente" 28 .

É, portanto, num ambiente favorável, com índios já contatados e sertões menos desconhecidos, mas também hostil, em particular devido à reação dos grandes proprietários fundiários, prontos a semear a cizânia entre índios e missionários, que os jesuítas vão formando e consolidando a construção de algumas aldeias. Ao serviço da Igreja e do Estado, esses missionários juntaram índios em povoações que deviam servir como postos avançados para a conversão dos gentios, bem como armazéns de mão-de-obra, de homens para a guerra e de mulheres para a procriação. Natuba era um desses lugares.

b) As lutas, os homens e a terra. Natuba, do levante de 1677 à criação da freguesia de Nova Soure

Em outubro de 1677, quando os índios se rebelaram e mataram o capitãomor Agostinho Pereira Bacellar, um clima tenso reinava em toda a região. As notícias de revoltas, os mandados de prisão contra os principais de algumas aldeias, as mortes em conflitos envolvendo índios e brancos eram fatos corriqueiros. Regiões do interior baiano, mais afastadas de Natuba, conheceram

\footnotetext{
26 ARSI, Bras. 3-II, fls. 90 e 91.

27 ARSI, Bras. 3-II, fl. 96.

28 ARSI, Bras. 3-II, fl. 94.
} 
uma verdadeira guerra em 1671, quando os paulistas chegaram para dar cabo dos índios que resistiam aos colonizadores. A guerra não dizia respeito apenas aos índios insubmissos, mas também aos outros que eram obrigados a combater ao lado dos portugueses, muitas vezes sob pena de verem a si mesmos, suas mulheres e filhos castigados e reduzidos à condição de escravos ${ }^{29}$. Dois anos mais tarde, D. Afonso Furtado de Mendonça, governador geral do Estado do Brasil, ordenou a prisão dos "principaes dos Tapuyas do Itapicuru, para os castigar muito bem pelo desaforo que usaram" 30 . O desaforo, ao que parece, consistia em terem fugido de alguma jornada preparada para fazer guerra a outros índios.

Cristóvão, o principal das aldeias de Natuba, já devia ter sido informado sobre a intenção dos brancos de que ele e muitos dos homens de sua tribo fossem se juntar a uma tropa para alguma entrada. Mais do que isso, desconfiava de que desta feita queriam, na verdade, tirá-los dali, levando-os a habitar noutro espaço a fim de melhor servir às necessidades do Estado e, quiçá, dos fazendeiros e lavradores que buscavam obter maior segurança contra ataques indígenas através do estabelecimento de aldeias nas proximidades das suas terras. Não obstante o fato de esses índios já estarem sendo cristianizados - como indica o próprio nome do principal, Cristóvão-, a relação com a sociedade colonial permanecia bastante instável. A questão não se prende aqui ao ponto de vista missionário que afirmou ser inconstante a alma do indíge$\mathrm{na}^{31}$. Neste caso, o problema é de outra natureza, envolvendo a terra, os homens e mulheres e o modo como a sociedade colonial desejava dispor deles. Apesar de todas as limitações documentais, pois o historiador vê-se restringido aos testemunhos oriundos da sociedade colonial, é possível vislumbrar o tipo de problema que podia se colocar para esses povos indígenas. A cada mudança territorial da aldeia, novos desafios ecológicos e sociais se impunham, aumentando consideravelmente os riscos de desagregação de sua cultura, de seu modo de vida. É preciso assinalar que, por vezes, era a própria sobrevivência do grupo que estava em jogo.

${ }_{29}$ Um bom exemplo disso vê-se em carta de Afonso Furtado de Mendonça, de 20 de julho de 1671, na qual o governador ordena aos capitães de algumas aldeias para que viessem com seus índios às imediações de Cachoeira para se juntar às tropas que estavam sendo organizadas para a realização de uma entrada aos sertões. Recomendava o governador que obedecessem a suas ordens "e não o fazendo mandarei os soldados de São Paulo a trazel-os presos, e a suas mulheres, e filhos para os castigar com (como) traidores, e ficarão escravos dos Capitães". Documentos Históricos, 1928, 4: 162.

30 Documentos Históricos, 1928, 8: 376.

31 Sobre a temática da inconstância dos índios ver o estudo clássico de Eduardo Viveiros de Castro (Viveiros de Castro, 2002: 181-264) e Arenz e Silva, 2014: 27-54. 
Os índios de Natuba se encontravam em uma zona ainda inabitada por colonos brancos e mestiços e, muito provavelmente, não desejavam partir dali e deixar para trás suas roças, suas casas e seu relativo sossego. As ordens partidas de Salvador permitem, contudo, pensar num trágico fim para o índio Cristóvão. E não só. Numa carta de 3 de fevereiro de 1678, dirigida ao Capitão-mor Domingos Rodrigues de Carvalho, que havia tido ordens de castigar os índios rebelados, recomendava-se que ele chamasse os principais das aldeias próximas a Natuba e os assegurasse de que havia levado ordens para punir apenas os culpados do assassinato de Agostinho Pereira. Também devia lhes dizer que "as mortes e prisões dos outros sucederam por desobedecerem, e se levantarem, e rebelarem, e que eles foram os que com isso fizeram e moveram a guerra, e por isso foram castigados"32. Não há notícias de quantos índios foram mortos, mas algumas correspondências de março e abril de 1678 apresentam números que variam entre 400 e 500 prisioneiros trazidos por Domingos Rodrigues de Carvalho ${ }^{33}$. O preço pela resistência foi bem alto. Todavia, a tragédia não culminou na extinção da aldeia, pois sabemos que em 9 de abril de 1678, o índio Tomás recebeu a patente de capitão dos índios de $\mathrm{Natuba}^{34}$, e as 4 ou 5 aldeotas que formavam a aldeia permaneceram no local em que se achavam e sob a direção dos jesuítas ${ }^{35}$. O evento, contudo, talvez tenha ganhado cores bem vivas na memória dos povos Kiriri, sobretudo se muitos missionários tiverem repisado entre eles a narrativa que, a partir de 1698, figuraria no Catecismo em língua Kiriri, do jesuíta Luigi V. Mamiani Della Rovere, colocada na epígrafe deste artigo $^{36}$.

Vinte anos mais tarde, em 1696, o jesuíta Alexandre Perier enviava ao rei uma carta que se constituía em verdadeira denúncia em relação à atitude dos poderosos da terra, em particular dos senhores da Casa da Torre, para com os índios. De algum modo, ela já refletia os ventos de um novo tempo em rela-

32 Documentos Históricos, 1928, 9: 58.

33 Documentos Históricos, 1928, 8: 281 e Documentos Históricos, 1928, 9: 60. Pedro Puntoni fala em 500 ou 660 prisioneiros, mas não indica fonte para esta última estimativa. Puntoni, 2002: 122.

34 Documentos Históricos, 1928, 13: 31-32.

35 Deve-se assinalar que durante algum tempo a instabilidade iria reinar nas aldeias da região, dando ocasião a massacres e à escravização de muitos índios, como testemunha frei Martin de Nantes. Nantes, 1979: 54 e ss.

36 Parece-nos apressada a análise de Sólon Natalício Araújo dos Santos, que, sem atentar para o fundo factual do relato usado pelo padre Mamiani Della Rovere, vê na passagem apenas "uma manipulação jesuíta que visa atemorizar os índios aldeados com uma ameaça legal de "guerra justa" e escravidão caso fossem hostis com os colonos e missionários". Santos, 2011: 102 . 
ção à política da coroa e do governo do Estado do Brasil a este respeito. No reinado de D. Pedro II e governo de D. João de Lencastre, algumas medidas parecem indicar o fim de uma política repressora e de guerra contra os índios, que atingiu seu ápice a partir da chegada dos paulistas e entrega do governo da Conquista a Estevão Bayão Parente, em 1671. Assistia-se ao início de outro projeto, que tinha nos missionários o elemento fundamental para evangelizar e integrar essas populações na sociedade colonial. A determinação de João de Lencastre de demarcar terras para índios de aldeias do Zorobabé, no Rio São Francisco, em junho de 1696, é um exemplo disso ${ }^{37}$. Entretanto, as reações a essa mudança não se fariam esperar. A Casa da Torre, ou como dizia o Padre Alexandre de Gusmão em carta a D. João de Lencastre, a Senhora Rainha da Torre, Dona Leonor Pereira Marinho, não assistiria a essa demarcação de terras de braços cruzados. E naquele mesmo ano de 1696, mobilizando curraleiros, vaqueiros e índios, que se encontravam em suas terras, expulsou os jesuítas das missões do São Francisco ${ }^{38}$. Alexandre Perier não faz menção a esses eventos, mas cita o caso da missão de nova Jacobina, onde foi promovida uma rebelião a fim de expulsar o missionário jesuíta da aldeia. O ponto central foi sempre o da terra. Eis como o padre Perier entendia o problema:

Vossa Majestade fez mercê de seiscentas léguas de terra a um sujeito que com quatro facas de 30 réis e uns velórios se fez mestre a todos os sítios que tinham água. E agora, com 14 mil cruzados de renda de sítios, sem os que dá de graça e tantos currais próprios, alega serviços à coroa, tomando o jus Patronato, dizendo que eles porão missionários como põem e negam uma ou duas légua de terra aos pobres Índios que por serem brutos por qualquer bebida a tudo se sujeitam ${ }^{39}$.

Seu objetivo, na carta, era o de sensibilizar a coroa para que apoiasse a iniciativa governamental da demarcação de terras para os índios aldeados. Nesse sentido, buscava mostrar por vários modos a inocência dos tapuias e a impossibilidade de viverem sem um pedaço de terra para plantar. Ele, que havia missionado na aldeia de Natuba, lembrava a obediência daqueles índios a Deus e ao rei. Dizia que, numa epidemia ocorrida naquela aldeia, sem poder socorrer a todos

... despois de confessados me mandavão logo chamar para que lhe desse a Sta. Unção; e porque eu não podia dar este sacramento sem estarem em perigo, me

\footnotetext{
37 AHU, CU, Bahia-Luisa da Fonseca (LF), cx. 32, doc. 4096.

38 A principal documentação relativa ao caso se encontra em AHU, CU, Bahia-LF, cx. 32, docs. 4083-4098.

39 AHU, CU, Bahia-LF, cx. 32, doc. 4097.
} 
respondião que não me angustiasse em buscar lhes de comer porque recebida a Sta. Unção Bui ietcá Tupá que em língoa de Tapuia quer dizer hiria ver $\underline{\text { a Deos }}^{40}$.

Já quando o governo requisitou índios para o serviço do salitre, enviou 80 e depois mais 60 homens, todos de vinte a trinta anos de idade. Nenhum desses índios fugiu ao serviço e teriam feito tudo sem outra esperança do que a de ganhar um papel certificando a prestação de serviços à coroa, ou como escrevia Perier "hua meia folha de papel em que ponhão que tem servido a El Rey legitimo seu Senhor porque não são tão Brutos que não conheção que só Del Rey são vassalos e do Governo, e não dos Senhores das Terras"41.

Haveria uma contradição no discurso do jesuíta, ao fazer do índio ora um bruto que se sujeitava a tudo movido pelo álcool, ora capaz de discernir a quem devia obediência? Não parece ser o caso. A divisão aqui seria antes a do índio aldeado e administrado por missionários e os outros que viviam em comunicação mais estreita com brancos e mestiços. O próprio governador D. João de Lencastre, numa carta de 1700, afirmava:

O Fruto que se faz nas Aldeas hé conservalos na fé e procurar de afastalos da ebriedade e feitiçarias e deshonestidades que são os vícios mais frequentes entre os Indios domésticos, dos quais são mais retirados os Tapuyas do Certão, parte por inclinação própria e parte por não verem em seos dizertos os máos exemplos dos brancos $^{42}$.

Trata-se de um interessante argumento para entender a vontade de manter as aldeias mais afastadas de povoações de brancos. De fato, a demasiada proximidade de fazendas e povoados das aldeias já havia passado a ser entendida como uma séria ameaça para a vida indígena, bem como para o modelo de vida que os missionários procuravam impor na administração desses povos. Não fosse pelas razões elencadas pelo governador, seria por outras manifestadas pelo padre Francisco de Mattos numa carta também de fins do século XVII. Nela, o provincial da Companhia de Jesus diz que os portugueses se opõem ao alojamento dos

Indios junto de nossas povoações, allegando contra a sua vizinhança, que as terras são suas, e lhes forão dadas por sismarias, ou compradas com o seu dinheiro e não devão consentir nellas a Indios, como se ve na oppozição prezente de Francisco Dias de Avila, e se viu em outra antiga de seu tio o Pe. Antônio Pereira. E sendo o Brazil dos Indios por natureza, lhes não queremos dar em suas mesmas
40 Idem.
41 Idem.
42 AUC, Col. Conde dos Arcos, VI-3-1-1-5, fl. 687v. 
terras a habitação, q ella lhes deo; e isto ainda aos Indios já convertidos, que por christãos, havendo de ser mais bem tratados, ficão de peior condição do que os gentios, pois estes na vastidão de seus mattos vivem com toda a largueza de sitios sem dependencia alguma das merces dos Portuguezes ${ }^{43}$.

A terra, sempre a terra, está no centro do problema. No caso de Natuba, na última década do século XVII, há claros vestígios de conflitos fundiários ${ }^{44}$. Dona Joana Pimentel e Manoel Garcia Pimentel, respectivamente viúva e filho do poderoso senhor Francisco Gil de Araújo, que além de possuir muitas terras na Bahia, foi donatário da Capitania do Espírito Santo, peticionava à coroa a suspensão de uma provisão que o jesuíta Miguel Pinto, superior da aldeia de Natuba, havia conseguido. Tratava-se de contestar uma ordem de despejo de quatro currais de gado bovino estabelecidos em locais próximos à aldeia. Na petição, a família Araújo Pimentel tratava de sustentar a precedência da posse daquelas terras em relação à criação da aldeia. Afirmava que os índios haviam chegado à região de Natuba após terem sido expulsos das terras do padre Antônio Pereira. Noutras palavras, associava a formação da aldeia ao momento da destruição, pelos D'Ávila, das igrejas das aldeias do Massacará, Jeremoabo e Itapicuru, em 1669. Dizia que, após esses fatos, "vendo-se o dito superior corrido, e os mesmos índios vexados, se foram valer do marido, e pay dos suplicantes, que os recolheo com amor nas ditas suas terras da Natuba onde estiveram sempre com socego, e sem perturbação alguma em suas lavouras thé o prezente" 45 .

O expediente usado pela viúva e seu filho para defender a posse das terras era bastante comum e, como noutros casos, se fazia seguir pelo argumento de que os jesuítas, sob pretexto de defender os índios, queriam tornar-se senhores das terras e de seus gados ${ }^{46}$. A história contada não é muito crível, afinal, todas as aldeias existentes nas terras dos D'Ávila continuaram a existir. Na região mais próxima a Natuba pode-se constatar a seguinte situação: a aldeia de Itapicuru passou a ser administrada por franciscanos, 10 e 15 léguas para o Norte estavam as aldeias de Canabrava e Saco dos Morcegos, administradas por jesuítas, que

43 Biblioteca do Palácio Nacional da Ajuda, Lisboa (BAJ), cod. 50-V-37, doc. 84, fl. 243.

44 Não encontramos para o caso de Natuba, ao menos até a expulsão dos jesuítas, registros de aforamentos de terras indígenas como os descritos por Maria Regina Celestino de Almeida para algumas aldeias do Rio de Janeiro (Almeida, 2000: 244-260). É provável que a situação tenha se modificado após a transformação da aldeia na Vila Nova de Soure, em 1759.

45 AUC, Col. Conde dos Arcos, VI-3-1-1-6, fl. 414. Embora não haja data na cópia da petição, data de 14 de dezembro de 1696 a carta régia enviada a D. João de Lencastre pedindo-lhe informações sobre o conteúdo da petição.

46 AUC, Col. Conde dos Arcos, VI-3-1-1-6, fl. 414. 
também administravam a aldeia do Jeru, em Sergipe Del Rey, a cerca de 16 léguas de distância de Natuba. Digno de nota, entretanto, é a força com que os grandes proprietários procuravam resguardar suas terras. Quando se tratava de defendê-las esfumavam-se quaisquer alianças e simpatias anteriormente existentes. Com efeito, Francisco Gil de Araújo, em 1655, havia se comprometido a doar 30 mil cruzados para a construção da capela-mor da Igreja dos jesuítas na Bahia. Sua família, como se pode inferir das informações constantes em carta do vice-reitor do Colégio da Bahia, Simão de Vasconcelos, era uma forte aliada da Companhia de Jesus ${ }^{47}$. Contudo, quatro décadas passadas, um pedido de demarcação de terras para índios resultaria numa reação enérgica da família contra os jesuítas. Reação que parece ter sido bem sucedida, pois em 19 de fevereiro de 1698 a coroa ordenava ao governador geral executar a sua decisão de fazer com que "o Chanceler da Relação desse Estado com dois Desembargadores mais antigos tomem conhecimento desta matéria ouvidas as partes interessadas, e que determinem o que lhes parecer justiça, sem apelação, nem agravo"48.

A promulgação do Alvará em forma de lei, de 23 de novembro de 1700, que mandou dar uma légua de terra a cada missão, não alteraria imediatamente a situação ${ }^{49}$. É o que deixa ver a petição do jesuíta Antônio de Andrade, solicitando novamente, em 1716, a demarcação de terras para os índios de Natuba, que àquela altura contava com $800 \mathrm{almas}^{50}$. O requerimento do missionário fez com que D. João V desse ordem ao Vice-Rei, o Marquês de Angeja, para enviar o ouvidor geral ao local a fim de fazer as demarcações. Na mesma ordem, o rei retomava argumentos avançados pelo procurador dos jesuítas, dizendo que no momento da construção das cinco aldeotas que formavam a aldeia de Natuba

\begin{abstract}
... não havião moradores, mas por que não lhe assinarão nem demarcarão logo terras na forma de minha Provisão real se forão ocupando as terras vizinhas a ellas com fazendas de gados de tal sorte que hoje não tem palmo de terra, antes está cercada e oprimida com 3 fazendas de gado, hua q não dista della mais que um tiro de mosquete, e as outras duas não mais que meio $4^{\circ}$ de légua ${ }^{51}$.
\end{abstract}

47 Eis um pequeno extrato da carta de 9 de outubro de 1655: "o Capitão Francisco Gil de Araujo quis tomar a sua conta a capela mor da Igreja com titulo de fundador dela dando para isso trinta mil cruzados pagos em dez annos, a tres mil cruzados por anno, com promessa que se as safras de suas copiozas fazendas forem florentes nesses annos em que o forem dobrará os tres mil cruzados pagando seis, do que não duvidamos desta e de outras maiores liberalidades com que ha de ajudar; [...] porque he homem mui liberal, mui pio e afeiçoado a nossas couzas...", ARSI, Bras. 3-1, fl. 291-292v.

48 AHU, CU, Cartas da Bahia, cód. 246, fl. 66.

49 AHU, CU, Provisões, cód. 95, fl. 91v-92v.

50 AHU, CU, Bahia Avulsos, cx. 11, doc. 917.

51 Documentos Históricos, 1928, 64: 70. 
Não obstante a ordem régia, o problema continuaria a se arrastar por alguns anos. Em 1720, o Conselho Ultramarino ainda se debruçava sobre a questão. O procurador da coroa havia relatado a dificuldade de resolvê-la, pois "ainda que as terras fossem destes índios, se acham em terceiros possuidores, que com título honroso e boa fé as têm adquirido pelo lapso de muitos anos", não sendo justo que fossem despejados sem serem ouvidos ${ }^{52}$. Sem embargo das dificuldades relatadas, o Conselho foi de parecer que o Alvará de 23 de novembro de 1700 era claro em sua intenção de "infalivelmente" dar terras aos índios aldeados para poderem subsistir. E com vistas a frustrar quaisquer obstáculos ou pretextos à sua execução, consideravam conveniente que o rei declarasse que o alvará haveria de ser cumprido "assim a respeito desta aldeia de Natuba como de todas as mais daquele Estado, dando-se-lhe a terra que se lhe assinala na dita lei, não obstante ser possuída por donatários sesmeiros ou outro possuidor por qualquer título que seja"53.

Os pareceres do Conselho Ultramarino, corroborados pela própria coroa, poderiam fazer crer que, enfim, o problema da demarcação das terras indígenas teria um feliz desfecho. Todavia, distante da corte de Lisboa e nas lonjuras dos sertões encontra-se sempre alguma maneira de dar um caminho diferente às ordens régias, quase que invariavelmente em desfavor dos mais humildes. E, de fato, a situação dos índios de Natuba não mudou substancialmente. Numa súplica de fins dos anos 1720, o mesmo padre Antônio de Andrade, superior da missão de Natuba, dizia que as terras concedidas aos índios pela coroa - provavelmente aquelas demarcadas no início da década, a seu pedido - não passavam dos lodos de uns brejos onde só se podia plantar no verão, e sempre com o risco de ver tudo perder-se por conta das enxurradas. Mostrava, entretanto, saber que aquela situação era fruto de informações menos verdadeiras que foram dadas sobre as terras. Mais ainda, lembrava que o principal da aldeia, seu Capitão-mor, havia participado daquele negócio, "Se bem que hoje o dito Indio Capitão-mor está assás arrependido e causa compaixão não só porque os outros Indios, depois que souberão de sua traição intranhavelmente o aborrecem, chamando-lhe de mentiroso e traidor", mas também pelos maus tratos que padecia do senhorio da terra, Gaspar Carvalho da Cunha ${ }^{54}$. Sobre este fazendeiro o jesuíta diz que

... antes foy servo, e feytor de escravos no Recôncavo da Bahia, e hoje naquele sertão he Senhor de seis citios com muito gado e Capitam da ordenança. Dizia

\footnotetext{
52 Ibidem, 97: 215.

53 Idem.

54 AHU, CU, Bahia Avulsos, cx. 33, doc. 3042.
} 


\begin{abstract}
ainda que ele tratava ao dito Indio Capitam mór e aos mais índios, como escravos de seus escravos, mandando prender a estes por qualquer cauza e trazelos a sua presença, amarrados, permitindo que lhes tomem os seus brejos e os maltratem gravemente com pancadas e feridas ${ }^{55}$.
\end{abstract}

Da nova súplica resultou uma provisão datada de 21 junho de 1730, ordenando nova demarcação de terras a ser realizada pelo ouvidor geral da Comarca da Bahia, na conformidade do que havia sido estabelecido pelo Alvará de 23 de novembro de $1700^{56}$. Contudo, não encontramos vestígios documentais que permitam saber o que resultou da nova demarcação. Sequer é possível afirmar que ela tenha sido efetivamente realizada. O que se pode dizer com certeza é que com ou sem a nova demarcação, a situação de pobreza dos índios não iria sofrer maior alteração até o final dos anos 1750, quando interveio a expulsão dos jesuítas e a transformação da aldeia de Natuba na Freguesia de Nossa Senhora da Conceição de Nova Soure ${ }^{57}$.

Como outras aldeias, Natuba era paupérrima. Numa provisão régia de 1721 ordenava-se o pagamento de dois mil cruzados de esmola para a construção de uma nova igreja na aldeia. Retomando, provavelmente, algumas passagens do requerimento do padre Antonio de Andrade que deu origem à provisão, dizia-se que a "missão contava ao prezente de outocentas e tantas almas, e que pella sua muyta pobreza nunca pudera levantar Igreja capaz de tanto povo senão hua pequena de pao e barro que estava já arruynada" 58 . A crer no relato do vigário de Nossa Senhora do Nazareth de Itapicuru, padre José de Goes Araújo e Vasconcellos, feito em 1757 — pouco tempo antes de Natuba ser erigida em vigairaria - a igreja àquela altura estava bem ornada ${ }^{59}$. Este indício de que houve reforma ou construção de um novo templo em Natuba não modificava a sua condição de extrema pobreza. Tornada freguesia, somente padres em início de carreira ou que não tivessem melhores perspectivas pleiteavam tal paróquia, pois sabiam que para sua subsistência contariam, provavelmente, apenas com o dinheiro de sua porção côngrua. A pobreza dos índios não permitia que tivessem esperança de obter alguma renda substancial com conhecenças e pés-de-altar. O primeiro vigário de Nova Soure, Francisco Marques Quaresma, nascido em Salvador, tinha cerca de 27 anos quando foi aprovado no concurso para aquele benefício, chegando a ser provido como

\footnotetext{
55 Idem.

56 Documentos Históricos, 1928, 64: 65-67 e 67-69.

57 Sobre a execução do diretório pombalino na Bahia ver, notadamente, o estudo de Fabrício Lyrio dos Santos (Santos, 2014).

58 AHU-CU, Bahia Avulsos, cx. 24, doc. 2182.

59 AHU-CU, Bahia Castro e Almeida, cx. 15, doc. 2711.
} 
vigário colado daquela paróquia, mas desistiu ${ }^{60}$. Em 1766 ele se candidataria e seria provido em outra paróquia, a de Nossa Senhora do Monte ${ }^{61}$. Em razão da desistência de Francisco M. Quaresma, o benefício foi novamente posto em concurso, tendo sido provido como vigário colado o clérigo de ordens menores Antônio Barroso de Oliveira, de 28 anos, que permaneceria como pároco por pouco mais de três lustros, até tornar-se vigário de Santo Amaro da Ipitanga, em 1783, uma freguesia de recursos menos diminutos do que Nova Soure ${ }^{62}$. Em 1786, a vigairaria da antiga aldeia de Natuba voltaria a ser provida. Desta vez pelo menorista Francisco Estevão Tavares, que havia sido o único a candidatar-se àquela paróquia vaga ${ }^{63}$.

A exemplo de diversas localidades do semiárido baiano, Nova Soure permaneceria por muito tempo sendo identificada como uma povoação indígena. O testemunho de um capuchinho italiano, em 1804, é muito eloquente sobre o assunto. Além disso, contribui para demonstrar a continuidade da pobreza e a leitura que dela poderia ser feita por alguns homens, religiosos ou não. Frei Apolônio de Todi era um daqueles missionários que tinham uma visão bastante preconceituosa a respeito dos índios. Considerava-os "de nenhum préstimo, por serem falsos, preguiçosos, vingativos e luxuriosos ao último excesso", também estava convicto de que não poderiam ser atraídos com riquezas, por não fazerem "caso nenhum dos bens do mundo" 64 . As críticas ao abandono do modelo de governo dos índios que prevalecia à época de D. João $\mathrm{V}$ e à adoção do diretório pombalino soam como corolário de sua opinião negativa acerca dos indígenas.

... falando eu com o Capitão mór dos Indios da Villa de Sore e mais da Villa de Mirandella no anno de 1782, em que fiz missão, e falando deste novo directorio

60 AHU, CU, Bahia Avulsos, cx. 138, doc. 10657.

61 ANTT, Mesa da Consciência e Ordens (MCO), Padroados do Brasil, mç. 1.

62 ANTT, MCO, Padroados do Brasil, mç. 1.

63 Idem. A pobreza da aldeia também deu lugar, no século XIX, à resistência dos índios em atender às cobranças de direitos paroquiais. É isto que se vê em ofício do Diretor dos Índios, Antonio Ferreira de Brito, datado de 13 de maio de 1839, no qual se defende das acusações contra si proferidas pelo padre João Dias de Andrade, vigário de Soure. Segundo o diretor, aquele pároco queria cobrar direitos paroquiais dos índios, sendo que "sempre foi costume imemorial nesta freguesia e villa que os Indios, e os que dele procedem, e taes se denominão e arollão, e vivem unicamente da lavoura e pesca, não pagarem direitos paroquiais, nem fábricas, e durante cincoenta anos q foi vigário o finado Francisco Estevão Tavares, antecessor do actual, assim se praticou". Arquivo Público do Estado da Bahia, Salvador (APEB), C-P, Judiciário. Juízes Soure, maço 2611. Este documento me foi comunicado por Maria Rosário G. Carvalho, a quem muito agradeço.

${ }^{64}$ Lisboa, 1835: 183. 
para convence-los da brutalidade dos seus governos, me responderão: "Sr. Padre Missionario, Sua Magestade muito nos tem honrado com este directorio, pois nos declarou brancos, e com os privilégios dos brancos, porém de que serve quando nos deixou o mesmo coração, e ficando o mesmo coração, sempre obraremos de Indios, e não de brancos" ${ }^{65}$.

Não obstante todos os questionamentos que possam ser feitos à veracidade do testemunho invocado pelo capuchinho, há algo que merece nossa atenção. Obrar como índios e não como brancos é uma frase que, para o capitão-mor de Soure, podia ter um sentido bem diferente daquele intentado por Apolônio de Todi. A prevalência do modo de vida indígena, a ausência de preocupação em acumular riquezas, o gosto pela caça e pela pesca, a agricultura de subsistência ${ }^{66}$ e outros tantos traços culturais eram os sinais de que continuavam sendo índios - em seu coração, em sua alma - e de que não compartilhavam inteiramente o modo de vida da sociedade colonial. Se, por um lado, essas características explicam parcialmente a sua inerente pobreza, afinal não faziam caso dos bens do mundo, por outro lado, podem ser entendidas como uma escolha política daqueles índios que, sob capa de humildade e ignorância, mantêm seus costumes ${ }^{67}$. Seria necessário adentrar o século XIX para assistir a uma verdadeira mudança dessa realidade e perceber como, de modo lento e gradual, Nova Soure foi deixando de ser referida na documentação como uma freguesia de índios.

\section{CONSIDERAÇÕES FINAIS}

A escrita deste texto só foi possível através do esforço metodológico de cruzar vários fundos documentais e analisar fontes eclesiásticas e da administração estatal. Este caminho se impôs menos como escolha do que como via

65 Ibidem: 190.

66 Alguns desses traços são apontados no Ofício encaminhado pela Câmara Municipal da vila de Soure, dirigido à Presidência da Província (Vila de Soure, 27 de outubro de 1869). APEB, Câmara Municipal da Vila de Nova Soure, maço 1444 (1824-1889), citado por André de Almeida Rego (Rego, 2014: 282).

67 É preciso sublinhar que os ameríndios não tiveram diante deles um imenso leque de escolhas face às crescentes pressões exercidas pela sociedade colonial. Como bem escreveu John Monteiro, a resistência dos índios não se limitava "ao apego ferrenho às tradições précoloniais mas, antes, ganhava força e sentido com a abertura para a inovação". Monteiro, 2001: 75. No caso dos índios de Mirandela e Natuba, as inovações já se construíam ao longo de um século sob a administração missionária dos jesuítas. A condição de freguesia, a partir de 1757 , talvez tenha dado ensejo a novas possibilidades para aquelas comunidades se repensarem, mas também pode ter aberto a porta a novas pressões da sociedade colonial que exigiam novas respostas. 
que pareceu incontornável para alcançar uma visão menos turva sobre a relação entre as sociedades indígenas e o império português, entendido aqui como o poder do Estado, da Igreja, mas também dos agentes privados que constituíram uma parte fundamental da construção colonial.

A tentativa de centrar o estudo sobre uma microrregião e, em particular, uma aldeia, talvez tenha contribuído para confirmar nossos conhecimentos acerca de algumas questões gerais e levantar pistas sobre outras tantas que merecem investigações mais aprofundadas. O problema da terra, bem conhecido entre nós, vê-se novamente, no caso de Natuba, como um ponto central de disputas. Ligado a ele, entretanto, emerge uma questão instigante sobre aqueles que disputam a propriedade da terra. $\mathrm{O}$ caso estudado mostra que pode haver variação no perfil dos grupos que disputam a delimitação do território indígena. Viu-se que, em determinado momento, a demarcação das terras foi questionada por uma família detentora de grandes propriedades fundiárias, a viúva de Francisco Gil de Araújo e seu filho. Noutra quadra, desaparece a figura do latifundiário e surge a de um médio proprietário, um ex-escravo, que também havia sido feitor de escravos no Recôncavo baiano e que, mais tarde, veio a tornar-se senhor de terras e de escravos. Em curto espaço de tempo - apenas três décadas separam o requerimento de Joana Pimentel (1696) da petição do jesuíta Antônio de Andrade (1729)—, Gaspar Carvalho da Cunha tornou-se um potentado local e parece ter tido papel decisivo na frustração da demarcação de terras para os índios de Natuba ${ }^{68}$. Em sua ação, fez uso do aliciamento de uma liderança indígena, que com seu falso testemunho contribuiu para impedir que fossem dadas à aldeia as terras pleiteadas. O caso é particularmente interessante porque faz emergir a complexidade das relações existentes entre os próprios índios bem como entre estes e a sociedade colonial.

A mudança na escala de observação proporciona um conhecimento que pode contribuir para nuançar ou colocar em xeque sistemas explicativos gerais baseados em pares dicotômicos como metrópole/colônia, colonos/índios, missionários/colonos, dominantes/dominados etc. Ao ajustar as lentes para a ação de indivíduos, buscando observar seus perfis sociais, a despeito de todas as limita-

68 O poder e riqueza de Gaspar Carvalho da Cunha seriam transmitidos ao seu filho, Bernardo Carvalho da Cunha, que, como seu pai, foi capitão de ordenanças de Itapicuru. Este, em 1789, legitimava a Quintino Carvalho da Cunha, seu filho natural — havido numa relação adúltera que teve, quando ainda era solteiro, com Anna Maria da Conceição, mulher branca e casada-, com o intuito de torná-lo seu herdeiro (AHU-CU, Bahia - Castro e Almeida, d. 13415-13420). Quintino herdou os bens de seu pai e deu continuidade à trajetória de poder e riqueza dos Carvalho da Cunha em Nova Soure. Ver sobre o assunto o estudo de Mônica D. Dantas (Dantas, 2007: 57-70). 
ções impostas pelos vestígios documentais, a história flagra dramas que não se encaixam em modelos demasiado generalizantes. O ex-escravo, depois feitor de escravos, que se torna fazendeiro e inimigo de índios; a liderança indígena que trai a sua comunidade que depois o renega; os missionários que são a ponta de lança do esforço de conversão religiosa dos índios, cujo objetivo, além da salvação das almas, é o de enquadrá-los na sociedade colonial, também cumprem um papel fundamental. O exemplo mencionado acima, que toma por base o testemunho de frei Apolônio de Todi, não deve servir como prova da existência de uma clivagem mais profunda entre missionários de diferentes congregações religiosas. A visão daquele capuchinho acerca dos índios não é compartilhada por todos os missionários de sua ordem. Frades como Martin e Bernard de Nantes, que atuaram um século antes dele nas aldeias do São Francisco, são bons exemplos de uma concepção bem menos preconceituosa sobre os índios ${ }^{69}$. Por outro lado, nem sempre as ações dos jesuítas convergiram com os interesses dos índios. É difícil encontrar documentação sobre o assunto. Mas o rompimento do silêncio das fontes por vezes aparece através de um rebelde ou de uma rebelião. Por esta razão, mais do que buscar falas de índios, cumpre atentar aos gestos que denotam a divergência, a resistência negociada ou aberta. Eloquente exemplo disso é o de Aleixo, capitão-mor dos índios da aldeia jesuíta de Canabrava, destituído do seu posto pelo governador geral, por volta de 1724, a pedido do reitor do colégio da Companhia de Jesus. Era acusado de insolente e, após sua destituição, continuou em sua rebeldia, "sendo motor de sublevações". Por este motivo foi exterminado para o Rio de Janeiro. Em novembro de 1734, sabia-se que Aleixo havia voltado pelo caminho das Minas e encontrava-se numa região próxima à Mata de São João, onde estava juntando índios Kiriri e ia "decipando as missões da Natuba, Saco dos Morcegos e da mesma Canabrava"70. Certamente, Aleixo, em sua incrível história de resistência frontal, mas sobre a qual conhecemos tão pouco, representa a recusa ao modelo de vida que a sociedade colonial, através da mediação missionária, propunha aos índios.

Apesar de tudo, frente a uma realidade que mesclava a falta de limites dos senhores de terras em exercer seu poder e um Estado sem força - ou, por vezes, sem vontade - para punir os excessos dos poderosos e mesmo daqueles não tão poderosos, os aldeamentos dos missionários (jesuítas, franciscanos

69 Veja-se, por exemplo, a Relação de Martin de Nantes (Nantes, 1979). Para Cristina Pompa, houve uma mudança efetiva na visão capuchinha sobre o índio. Tratar-se-ia de um processo iniciado no período da implantação do Diretório pombalino e da expulsão dos jesuítas, que aos poucos foi desconstruindo a imagem do índio "em equilíbrio entre a servidão ao demônio e a pureza primordial de uma tábula rasa", substituindo-a por aquela do ser indolente, preguiçoso e falso (Pompa, 2011: 288-289).

70 Documentos Históricos, 1928, 76: 29. 
conventuais, capuchinhos, carmelitas) poderiam aparecer como alternativa menos danosa para muitos índios. Embora a canonização dos missionários não resista a um bom advogado do diabo, parece inegável que, no caso específico do Nordeste da Bahia, no período em tela, eles foram os principais aliados dos índios. De modo geral, os que escolheram a via do aldeamento missionário parecem ter tido melhor sorte em termos de sobrevivência e de reconfiguração identitária do que os índios que ficaram sob a administração de proprietários fundiários e/ou sacerdotes seculares.

A aldeia dos Mongurus, em Jeremoabo, é um bom exemplo disso. Embora criada por missionários jesuítas, vimos acima que sua igreja foi destruída e os missionários expulsos daquela região pelos senhores da Casa da Torre. Os franciscanos que, algum tempo depois, viriam a substituir os inacianos nas aldeias daquela área, missionaram por muitos anos na aldeia de Massacará, mas em Jeremoabo permaneceram por muito pouco tempo ${ }^{71}$. Contudo, a povoação continuou a existir e, em 1718, a pedido do arcebispo da Bahia, D. Sebastião Monteiro da Vide, ela foi erigida como sede da freguesia de São João Batista do Jeremoabo, tendo por matriz provisória a capela de Nossa Senhora de Bro$\operatorname{tas}^{72}$. Nos anos 1720, encontramos notícias sobre os índios em correspondências do Governo Geral. Numa ordem de 1720, dirigida ao Mestre de Campo Gonçalo da Costa Timudo, mandavam-no "com todo o cuidado possível ajuntar os casais de índios que puder conduzir da sua Aldeia de Jeremuabo, e mais índios da mesma nação, acompanhando para esse efeito ao Capitão João Barbosa Rebelo, e soldados de sua Companhia". Na mesma ordem vê-se que o intento daquela mobilização era levá-los ao Piauí, onde deveriam ser entregues ao Sargento-mor Miguel de Abreu e Sepúlveda, que estava encarregado de estabelecer ali uma nova aldeia para servir de defesa contra as investidas de índios indômitos naqueles sertões ${ }^{73}$. Em 1725, o vice-rei Vasco Fernandes César de Menezes ordenava ao Capitão João Barbosa Rebelo, que detinha a posse de algumas fazendas arrendadas ao Coronel Garcia de Ávila Pereira, da Casa da Torre, não mais se intrometesse "no governo ou administração dos ditos índios

${ }^{71}$ AHU-CU, Bahia - Castro Almeida, d. 2717, contém uma descrição da freguesia de São João Batista do Jeremoabo feita pelo padre Januário José de Souza Pereira, em 1757.

72 AHU-CU, Bahia, Avulsos, d. 4089. A capela, seguramente, foi erguida no lugar da igreja de palha que havia sido destruída anteriormente. Em 1723, como narra o padre João Coelho Bessa na petição aqui referida, a igreja "feita de pedra e barro, mto. Velha, que hera de huma aldeia de índios", já se encontrava muito arruinada.

73 Documentos Históricos, 1928, 44: 4. A ordem foi emitida em nome da junta de governo provisório, composta pelo Arcebispo D. Sebastião Monteiro da Vide, Caetano de Brito e Figueiredo e João de Araújo e Azevedo. Note-se que a região de Oeiras, no Piauí, dista mais de 600 quilômetros de Jeremoabo. 
com o que se evitará a contenda" que tinha com o vigário. Os índios deveriam ficar "na mesma forma que estiveram sempre conservando-se naquela parte donde for a sua situação"74. Três décadas depois, os índios aparecem numa breve menção da relação feita pelo padre Januário Pereira. Descrevendo a povoação de Jeremoabo, sede da paróquia, dizia haver ali "252 pessoas de comunhão, entre brancos que não passam de cinco, pardos, mistiços, Indios e pretos captivos de hum e outro sexo"75. Essa descrição, que distingue apenas o número de brancos em relação aos demais, parece corroborar a hipótese de que, muitas vezes, os indígenas estariam compreendidos em categorias como pardos e mestiços, o que constituiria uma das explicações para o sumiço dos índios, ou ao menos de sua designação enquanto tais ${ }^{76}$.

É possível imaginar as reconfigurações identitárias ocorridas entre os índios de Jeremoabo. Essas reconfigurações, alimentadas pelo avanço da colonização, contribuíram para acelerar a invisibilidade dos índios, ao menos nas fontes documentais emanadas da administração política e eclesiástica. Visto sob uma ótica de longa duração, percebe-se que esse ocultamento dos índios dos registros documentais caminhou a passos largos para o desaparecimento da própria identidade indígena daqueles que habitaram em Jeremoabo. Testemunho eloquente desta realidade é o discurso proferido pelo Deputado Benevenuto Augusto de Magalhães Taques, na Câmara dos Deputados, em 1855, no qual discorre, entre outros assuntos, sobre a questão relativa ao destino das terras de antigas aldeias extintas. Em seu discurso, após informar que, à época em que exerceu o cargo de juiz de direito da comarca de Monte Santo, dirigiu ao tesouro nacional uma exposição sobre as terras do patrimônio dos índios da vila de Jeremoabo, o deputado diz:

Essa vila não é de creação antiga, porém a aldêa que foi substituda pela villa é de creação antiquíssima, de modo que nem figura no mappa das aldêas ou missões da província da Bahia (...) hoje até se nega que existisse a aldêa ou missão de Geremoabo; (...) na villa ainda se encontrão descendentes dos primitivos senhores do lugar, onde se achão com culturas, ainda que pequenas, em algumas porções do terreno circunvizinho à villa. Mas esse terreno, que era outr'ora do patrimônio dos índios, acha-se agora todo ocupado por particulares ${ }^{77}$.

O caso de Jeremoabo tende a reforçar a ideia de que sem a administração missionária talvez não tivessem chegado até nossos dias, com todas as suas idas e vindas, aldeias como a dos Kiriri de Mirandela, cujo nome no passado era

74 Documentos Históricos, 1928, 72: 166-167.

75 AHU, CU, Bahia - Castro Almeida, d. 2717.

76 Resende, 2003: 165 e ss.

77 Annaes do Parlamento Brazileiro, 1875: 211. 
Saco dos Morcegos, ou como a do Massacará, dos Kaimbé78. Mas a proteção oferecida pela administração missionária — cuja relevância era considerada na própria decisão dos índios de ali se refugiarem ${ }^{79}$ - não é, evidentemente, o único fator explicativo da perseverança da identidade indígena em algumas aldeias. Ao observar atentamente a situação geográfica das aldeias da mesorregião nordeste da Bahia percebe-se que a proximidade de uma importante via de comunicação pode ter contribuído para acelerar as transformações. Assim, aldeias como a de Canabrava e de Natuba, localizadas às margens de uma estrada real que ligava os sertões do São Francisco e partes de Sergipe del Rey à cidade da Bahia, não apresentam, ao longo dos séculos XIX e XX, o mesmo desdobramento histórico de povoações como Mirandela e Massacará, que se encontravam a maior distância de uma estrada mais movimentada. Este relativo isolamento pode ter reduzido a pressão da sociedade colonial e posteriormente nacional sobre eles, jogando um papel importante para a manutenção de seu modo de vida e de sua identidade. Todavia, cumpre notar que esta explicação funda-se em elementos que são percebidos como mais salientes e não exclui a percepção de que outros fatores de ordem ecológica, cultural, socioeconômica e política podem ter contribuído para a longevidade das aldeias indígenas mencionadas. Além disso, uma análise mais aprofundada sobre o tema não poderia prescindir de uma pesquisa sobre a situação dessas aldeias e povoações no século XIX ${ }^{80}$.

O problema da subsistência da identidade indígena — entendida em sua dinâmica cambiante de reconfiguração, conformando-se às exigências do contexto em que se inseria e às estratégias dos próprios índios-, embora deva ser analisado a partir da observação de múltiplos fatores intrínsecos e extrínsecos aos grupos indígenas aldeados, não invalida o interesse por um exame mais particular acerca do peso da ação missionária nas transformações culturais daqueles índios. Com efeito, uma combinação entre cristianismo e cultura indígena se fez a partir dessas missões e talvez ela tenha sido determinante para que alguns povos pudessem persistir, reconfigurando-se e incorporando o cristianismo, a seu modo, ao seu universo cultural ${ }^{81}$. Também deita origens nessa mis-

78 Sobre os Kiriri ver, entre outros, o artigo de Sheila Brasileiro e José Augusto Sampaio (Brasileiro e Sampaio, 2012: 147-166) e sobre os Kaimbé ver a dissertação de Jorge Bruno Sales Souza (Souza, 1996).

79 Almeida, 2000: 91-93.

80 André de Almeida Rego, cuja atenção volta-se para a história dos índios na Bahia do século XIX, apresenta, de modo esparso, vários indícios de grande interesse para a compreensão da sobrevivência dos grupos indígenas em povoações do nordeste baiano. Rego, 2014; 2016.

81 No que diz respeito ao catolicismo dos índios, o ponto de vista expressado aqui se aproxima daquele de Cristina Pompa (Pompa, 2003a: 415-416), que percebe a coexistência no "catolicismo indígena" de uma releitura, tradução e transformação de antigos mitos e rituais. 


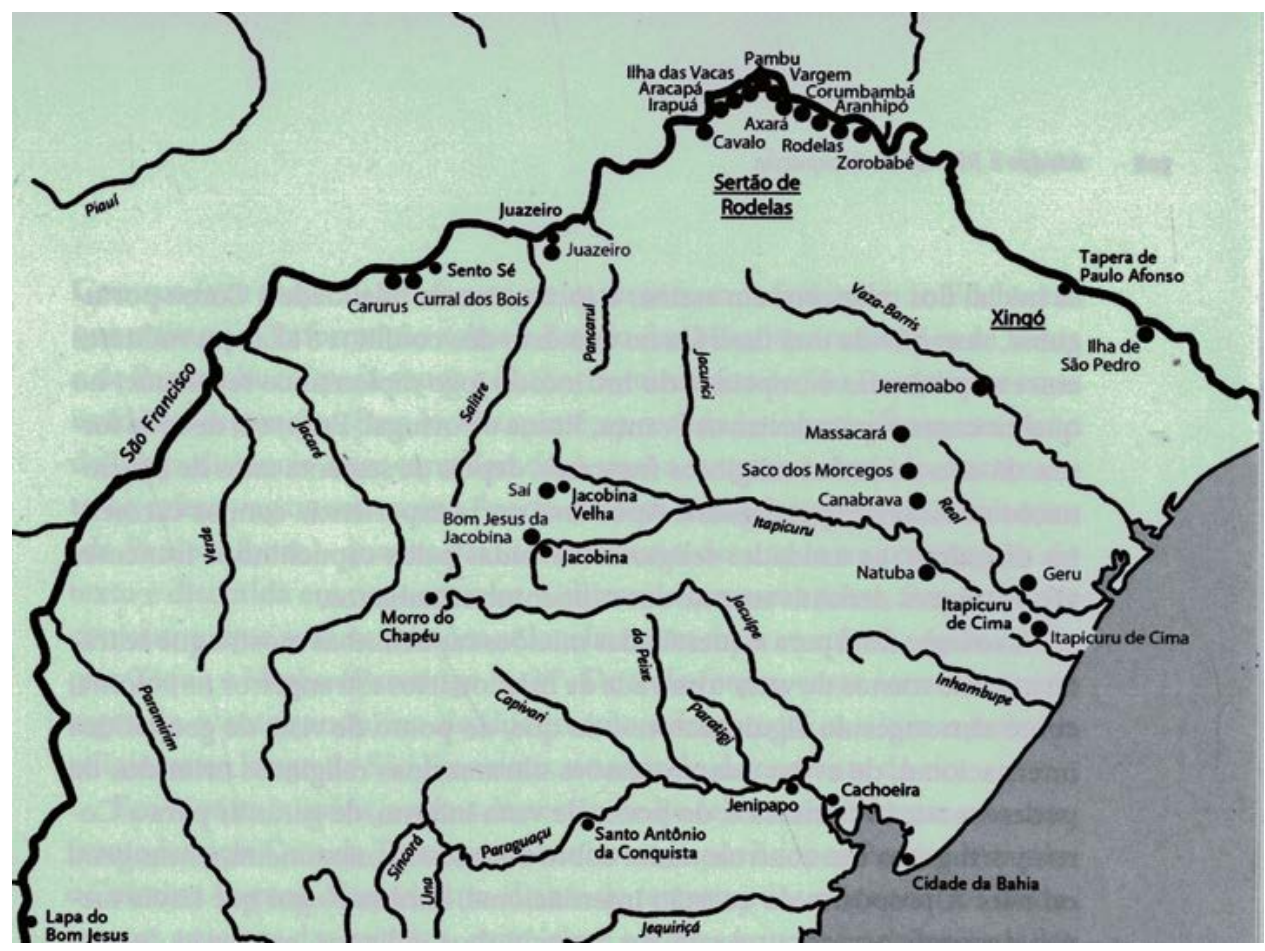

Fonte: Santos, 2017: 307.

tura um modo de crer e manifestar a crença que, durante muito tempo, marcou o catolicismo dos sertões baianos e de outras partes do nordeste do Brasil ${ }^{82}$. Ainda hoje, as festas dos padroeiros de algumas dessas aldeias e cidades estampam traços desse caldo religioso-cultural que teimam em não desaparecer. As zabumbas, com seus tambores e flautas, juntam música, dança e cachaça, num contexto de celebração religiosa, constituindo um excelente exemplo de manifestação produzida pela fusão de dois mundos ${ }^{83}$. Há, sem dúvida, várias outras

82 O belo estudo de Cândido da Costa e Silva sobre a paróquia do Patrocínio do Coité, a atual cidade de Paripiranga, localizada no Nordeste da Bahia, mostra com muita clareza alguns aspectos desse catolicismo. Silva, 1982.

83 Sobre as zabumbas ver a breve descrição feita por Maria de Lourdes Bandeira (Bandeira, 1972: 133). O leitor encontrará no link, a seguir, a gravação de uma zabumba de Ribeira do Amparo, município próximo a Nova Soure, https://www.youtube.com/watch?v=cKXYSTfd3c0. 
formas de expressão ou sensibilidade religiosa nas quais será possível flagrar os sinais de uma crença cristã que se desenvolveu no meio indígena. Uma forma de crer considerada débil por muitos homens de Igreja, que apontavam para a necessidade de expurgar os traços de gentilismo, supostamente, responsáveis por afastá-la do verdadeiro cristianismo. Mas uma crença que, observada em seu desenvolvimento histórico, foi suficientemente forte a ponto de tornar-se um traço distintivo da própria cultura indígena e da gente que se estabeleceu naqueles, outrora longínquos, sertões do nordeste da Bahia.

MAPA 2. DAS ALdeias de ÍNDIOS LOCALIZADAS

NA REGião ENTRE a VILA DE CACHOEIRA E NATUba

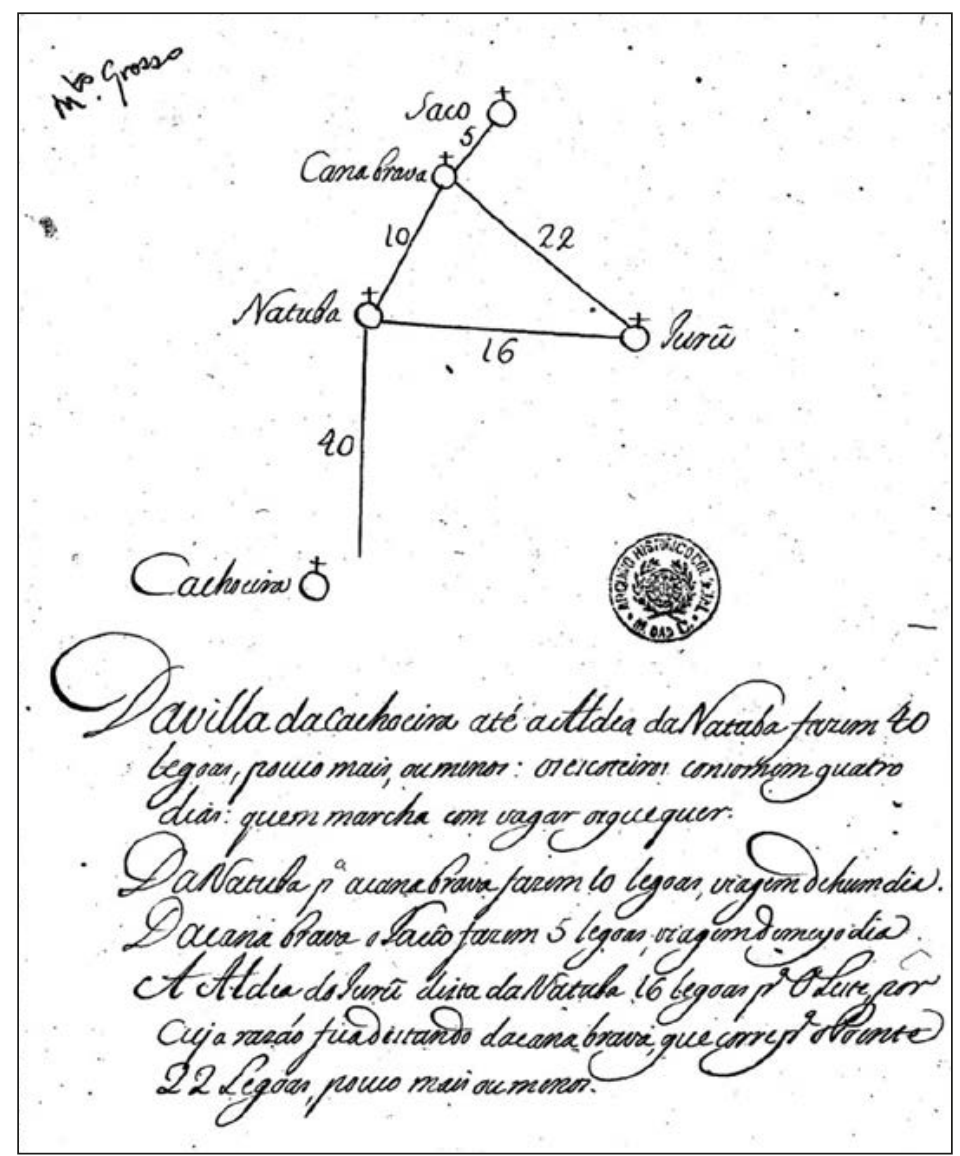

Fonte: AHU-CU, Bahia Avulsos, cx. 138, doc. 10673. 


\section{REFERÊNCIAS BIBLIOGRÁFICAS}

Almeida, Maria Regina Celestino de, Os Índios Aldeados no Rio de Janeiro Colonial, Campinas, IFCH-Unicamp, 2000. Tese doutorado.

Annaes da Bibliotheca Nacional do Rio de Janeiro, Rio de Janeiro, Officinas Graphicas da Bibiliotheca Nacional, 1909, vol. XXXI.

Annaes do Parlamento Brazileiro: Câmara dos Srs. Deputados, Rio de Janeiro, Tipographia do Imperial Instituto Artistico, 1875, vol. 3, partes 1-3.

Arenz, Karl Heinz e Silva, Zady Alberto da, "A murta murchando: o discurso jesuítico acerca dos índios aldeados na Amazônia Portuguesa (1653-1759)", Revista Ultramares, 5/1 (Maceió, Jan-Jul 2014): 27-54.

Bandeira, Maria de Lourdes, Os kariris de Mirandela: um grupo indígena integrado, Salvador, UFBA, 1972.

Barros, Francisco Borges de, Bandeirantes e sertanistas bahianos, Salvador, Imprensa Oficial do Estado, 1919.

Brasileiro, Sheila e Sampaio, José Augusto L., "Estratégias de negociação e recomposição territorial Kiriri", Maria Rosário G. Carvalho e Ana Magda Carvalho (orgs.), Índios e caboclos: a história recontada, Salvador, EDUFBA, 2012: 147-166.

Calmon, Pedro, História do Brasil, Rio de Janeiro, Livraria José Olympio, 1959.

Dantas, Beatriz G., Sampaio, José Augusto L. e Carvalho, Maria Rosário G. de, “Os povos Indígenas no Nordeste Brasileiro. Um esboço histórico", Manuela Carneiro da Cunha (org.), História dos índios no Brasil, São Paulo, Companhia das Letras, 1992: 431-456.

Dantas, Mônica Duarte, Fronteiras movediças: a comarca de Itapicuru e a formação do arraial de Canudos, São Paulo, Hucitec/FAPESP, 2007.

Documentos Históricos, Rio de Janeiro, Biblioteca Nacional, Departamento Nacional do Livro, 1928.

Leite, Serafim, História da Companhia de Jesus no Brasil, Rio de Janeiro, Imprensa Nacional do Livro, 1945, tomo V.

Lisboa, Balthazar da Silva, Annaes do Rio de Janeiro, contendo a descoberta e conquista deste paiz, a fundação da cidade com a história civil e ecclesiastica, até a chegada d'El-Rei Dom João VI; além de notícias topográficas, zoológicas e botânicas, Rio de Janeiro, Na Typ. Imp. E Const. De Seignot-Plancher e Cia., 1835, vol. VI.

Mamiani della Rovere, Luigi Vincenzo, Catecismo da doutrina christãa na lingua brasilica da nação kiriri, Lisboa, Na Officina de Miguel Deslandes, 1698. 
Marques, Guida, "Do índio gentio ao gentio bárbaro: usos e deslizes da Guerra Justa na Bahia seiscentista", Revista de História, 171 (São Paulo, dez. 2014): 15-48, disponível em: http://www.revistas.usp.br/revhistoria/article/view/89006/91925.

Monteiro, John M., Tupis, tapuias e historiadores. Estudos de História Indígena e do indigenismo, Campinas, Unicamp, 2001. Tese Livre Docência em Etnologia/História Indígena e do Indigenismo.

Nantes, Martin de, Relação de uma Missão no Rio São Francisco. Relação sucinta e sincera da missão do padre Martinho de Nantes, pregador capuchinho, missionário apostólico no Brasil entre os índios chamados cariris, Rio de Janeiro, Companhia Editora Nacional/MEC, 1979.

Pompa, Cristina, Religião como tradução. Missionários, Tupi e Tapuia no Brasil colonial, Bauru, Edusc, 2003a.

Pompa, Cristina, "Cartas do Sertão: a catequese entre os Kariri no século XVII", Revista Anthropológicas, 7/14-1 e 2 (Recife, 2003b): 7-33.

Pompa, Cristina, "História de um desaparecimento anunciado: as aldeias missionárias do São Francisco, séculos XVIII-XIX", João Pacheco de Oliveira (org.), A presença indígena no Nordeste: processos de territorialização, modos de reconhecimento e regimes de memória, Rio de Janeiro, Contra Capa, 2011: 267-292.

Puntoni, Pedro, A Guerra dos Bárbaros: povos indígenas e a colonização do sertão nordeste do Brasil, 1650-1720, São Paulo, Hucitec, 2002.

Rego, André A., Trajetórias de vidas rotas: terra, trabalho e identidade indígena na província da Bahia (1822-1862), Salvador, PPGH-UFBA, 2014. Tese doutorado em História.

Rego, André A., "Legislação fundiária e extinção de aldeamentos na Bahia durante o período imperial”, Fabrício L. Santos (org.), Os índios na história da Bahia, Cruz das Almas, EDUFRB/Belo Horizonte, Fino Traço, 2016: 85-98.

Resende, Maria Leonia Chaves de, Gentios brasilicos: indios coloniais em Minas Gerais setecentista, Campinas, IFCH-Unicamp, 2003. Tese doutorado.

Salvado, João Paulo e Miranda, Susana M. (eds.), Cartas do I ${ }^{o}$ Conde da Torre, s.l., Comissão Nacional para as Comemorações dos Descobrimentos Portugueses/ Centro de História e Documentação Diplomática, MRE, 2001, vol. I.

Santos, Fabrício Lyrio dos, Da catequese à civilização. Colonização e povos indígenas na Bahia, Cruz das Almas, EDUFRB, 2014.

Santos, Márcio R. Alves dos, Rios e fronteiras. Conquista e ocupação do sertão baiano, São Paulo, Edusp, 2017.

Santos, Solon Natalício Araújo dos, Conquista e Resistência dos Payayá no Sertão das Jacobinas: Tapuias, Tupi, colonos e missionários (1651-1706), Salvador, Universidade Federal da Bahia, 2011. Dissertação mestrado em História. 
Silva, Cândido da Costa e, Roteiro da vida e da morte: um estudo do catolicismo no sertão da Bahia, São Paulo, Ed. Ática, 1982.

Silva, Ignacio Accioli de Cerqueira e, Memorias historicas e politicas da provincia da Bahia. Annotado por Dr. Braz do Amaral, Bahia, Imprensa Official do Estado, 1919.

Silva, José Justino de Andrade e (comp. e anot.), Collecção Chronologica da Legislação Portugueza, Lisboa, Imprensa de J. J. A. Silva, 1854.

Souza, Jorge Bruno Sales, Fazendo a diferença um estudo da etnicidade entre os Kaimbé de Massacará, Salvador, Universidade Federal da Bahia, 1996. Dissertação mestrado em Sociologia.

Viveiros de Castro, Eduardo, A inconstância da alma selvagem e outros ensaios de antropologia, São Paulo, Cosac \& Naify, 2002.

Fecha de recepción: 20 de enero de 2017.

Fecha de aceptación: 10 de abril de 2017.

\section{Misioneros, indios y sociedad colonial en el noreste de Bahía: Natuba, siglos XVII y XVIII}

El artículo examina aspectos de la conquista y población del noreste de Bahía, centrando la atención en el papel del indio en la ocupación colonial de nuevos espacios. Se toma la aldea de Natuba como la principal referencia para el estudio del contexto de la violencia que marca el avance de la sociedad colonial en la región. Tras estudiar el problema de la demarcación de tierras, que afectaba a indios, misioneros, gobierno y colonos, se muestra cómo la aldea misionera tendia a ser un espacio menos inestable, porque permitía a los indígenas avanzar por una senda de reconfiguración propicia a mantener su identidad, bajo la influencia de la tradición católica vivida en el noreste de Bahía.

Palabras ClaVE: Brasil colonial; indios; sociedad colonial; misioneros. 


\section{Missionaries, Indians and colonial society in Northeastern Bahia: Natuba, seventeenth and eighteenth centuries}

The article examines aspects of the conquest and settlement of the Northeast of Bahia, focusing on the Indians' role in the colonial occupation of new spaces. The village of Natuba is taken here as the main reference to study the context of violence that marks the advance of colonial society in the region. After examining the problem of land demarcation, which involves Indians, missionaries, government and settlers, reductions are shown to be a less unstable space, allowing the Indians to follow a path of reconfigurations that helped to maintain their identity and to influence the Catholicism experienced in the Northeast of Bahia.

KEY WORDS: colonial Brazil; Indians; colonial society; missionaries. 